\title{
Morpho-anatomical characteristics conferring drought tolerance in roots of sugar cane genotypes (Saccharum L., Poaceae)
}

\author{
Jean Rafael da Cruz Maciel ${ }^{1}$ - Danielle de Oliveira $^{2}$ - Dauri Aparecido Fadin ${ }^{3}$. \\ Maria das Graças $\mathrm{Sajo}^{4} \cdot$ Cristiano Pedroso-de-Moraes ${ }^{5}$
}

Received: 8 March 2015/Accepted: 29 June 2015/Published online: 18 July 2015

(c) Botanical Society of Sao Paulo 2015

\begin{abstract}
Sugar cane is a major product of Brazilian agriculture, providing about $\mathrm{R} \$ 56$ billion of exports per year. Morphological and anatomical analyses enable the identification of plants, whose genotype is still unknown, and increase our knowledge of organs adaptations, such as roots, to different environment conditions. This study aimed to describe the morpho-anatomy of roots of six sugar cane genotypes. Plants were obtained by insertion of stalks in $3 \mathrm{~L}$ containers filled with coconut fiber substrate. They were held for 7 days in a germination chamber (BOD MA 403) under a 16-h photoperiod with a light intensity of $38 \mu \mathrm{mol} \mathrm{m} \mathrm{m}^{-2} \mathrm{~s}^{-1}$ and a constant temperature of $35^{\circ} \mathrm{C}$. Daily irrigation was performed, keeping the substrate close to saturation. After this period, plants were transferred to a greenhouse and grew under approximately $116 \mu \mathrm{mol} \mathrm{m} \mathrm{m}^{-2} \mathrm{~s}^{-1}$ of light intensity at $30{ }^{\circ} \mathrm{C}$ and $80 \%$ relative humidity, during 45 days of daily irrigation. For anatomical characterization, 20 roots from stalks and tillers of five plants per genotype were fixed in
\end{abstract}

Cristiano Pedroso-de-Moraes

cpmoraes@gmail.com

1 Monsanto - Brazil, Estrada Municipal CHL 362, Km1. Fazenda Santa Fé, Conchal, SP CEP 13835-000, Brazil

2 Universidade Federal de São Carlos (UFSCar), Campus Araras, Rodovia Anhanguera, Km 174, Araras, SP CEP 13600-970, Brazil

3 Dow AgroSciences Brasil, Rodovia SP 147, Km 71.5 - Vila Primavera, Mogi Mirim, SP CEP 13801-540, Brazil

4 Departamento de Botânica, Instituto de Biociência Universidade do Estado de São Paulo (UNESP), Rio Claro, Caixa Postal 199, Rio Claro, SP CEP 13506-900, Brazil

5 Centro Universitário Hermínio Ometto (UNIARARAS), Av. Dr. Maximiliano Baruto, 500 - Jardim Universitário, Araras, SP CEP 13607-339, Brazil
FAA $50 \%$ and preserved in alcohol $70 \%$. For each root, the median region was selected for freehand-sectioning, using a razor blade. The results confirmed that anatomical features might be useful for cultivar identification. RB867515 cultivar showed roots with anatomical features that provide drought resistance, including a reduced number of cortical layers. The roots of SP801816 cultivar had more cortical layers and protoxylem poles in stalks and tillers, indicating a reduced drought resistance.

Keywords Cortex $\cdot$ Exodermis $\cdot$ Protoxylem poles $\cdot$ Root anatomy

\section{Introduction}

Saccharum L. species, popularly known as sugar cane, grow in tropical and subtropical regions between parallels $35^{\circ}$ North and South, where there is a warm and moist period, which provides good conditions for seed germination, vegetative growth, and tillering, associate with a cold and dry period, which promotes maturation and sucrose accumulation in stalks, making it ideal for farming this economically important crop (Caputo et al. 2008). This importance is related to its multiple utility. It can be used, for instance, to provide forage for livestock or converted to "rapadura" molasses, brandy, sugar, or alcohol. Its waste products are also of economic importance, such as the "vinhoto" being composted to form a mulch or used as fuel (Caputo et al. 2008). In Brazil, sugar cane provides a range of valuable exported products, as well as employment and income for rural workers. The sugar-alcohol market turns over about \$27 billion per year, with direct and indirect revenues corresponding to $2 \%$ of Brazilian gross domestic product (GDP) (Procana 2010). 
The continuing success of this economic activity relies on breeding programs able to develop varieties adapted to grow in diverse areas and to be resistant to disease and insect attacks (Rosse et al. 2002). The development of new varieties has increased worldwide interest in the characterization of sugar cane genotypes. This interest reflects the need to protect specific cultivars in an increasingly competitive market. Factors used to differentiate genotypes have included expensive biochemical and molecular procedures (Almeida et al. 2009). The present investigation explores the utility and economic benefits of using morphological characteristics to identify varieties.

Each cultivar has unique morphological features that enable its identification and characterization, including those of unknown genotype. These features range from variations in the morpho-anatomy of shoots to differences in the development and architecture of root system (Vasconcelos 1998). Anatomical studies of sugar cane roots were performed by Queiroz-Voltan et al. (1998) and Chaves et al. (2009); however, these authors did not focus on the use of root structure to differentiate genotypes currently cultivated by the sugar cane industry. In the present study, we aimed to describe the root morpho-anatomy and adaptations of six sugar cane genotypes. Our hypothesis was that anatomical characteristics could be used for cultivar identification and could potentially indicate which cultivars would be more or less adapted to different environmental conditions, particularly water scarcity.

\section{Materials and methods}

The genotypes used in this study came from the germplasm bank owned by the power plant São João, located in Araras city in the State of São Paulo, Brazil. The cultivars are specified as RB801816, RB867515, RB855453, SP801842, SP803280, and SP813250.

Plants were obtained by insertion of stalks into $3 \mathrm{~L}$ containers filled with a coconut fiber substrate. Then, they were held for 7 days in a germination chamber (BOD MA 403Marconi ${ }^{\circledR} /$ Brazil) under a 16 -h photoperiod with a light intensity of $38 \mu \mathrm{mol} \mathrm{m}{ }^{-2} \mathrm{~s}^{-1}$ at a constant temperature of $35{ }^{\circ} \mathrm{C}$. Daily irrigation was performed, keeping the substrate close to saturation. After this period, plants were transferred to a greenhouse and grew under approximately $116 \mu \mathrm{mol} \mathrm{m} \mathrm{m}^{-2}$ $\mathrm{s}^{-1}$ of light intensity at $30{ }^{\circ} \mathrm{C}$ and $80 \%$ relative humidity for 45 days, with daily irrigation. Each genotype had five replicates.

For anatomical characterization, 20 roots from stalks and tillers of five plants per genotype were fixed in FAA $50 \%$ and preserved in $70 \%$ alcohol (Johansen 1940). The median region of each root was selected for freehand-sectioning, using a razor blade. The sections were stained with $0.05 \%$
Safra-Blau (Bukatsh 1972) and mounted in glycerin. Histochemical tests were done in order to identify chemical compounds, primarily suberin and lignin, which are commonly found in Poaceae (Enstone and Peterson 2005) (Table 1). The results were recorded using a digital camera attached to a photomicroscope (Olympus $114{ }^{\circledR}$ model BX51).

Cortical, vascular cylinder, and metaxylem vessels diameters of each root were measured. The root diameter of stalk and tiller was taken $2 \mathrm{~cm}$ from the apex with the aid of a digital caliper (Digimess ${ }^{\circledR}$ ). For statistical analysis, the range of measured anatomical variables was first tested with Liliefors to confirm the normality of data. Once a normal distribution was established, analysis of variance (ANOVA) was performed, followed by Tukey test $(\alpha=0.05)$. The statistical software used was BioEstat 5.3.

\section{Results}

All roots are cylindrical and similar in structure, with three distinct regions: the epidermis, the proper cortex, and the vascular cylinder (Figs. 1-16). The epidermis is one-layered in the roots of stalks and tillers from all genotypes (Fig. 7-16). In some roots, the epidermis cells are polygonal in shape, and in the genotype SP803280, there are trichomes in the epidermis (Figs. 13, 15).

The cortex has three distinct regions: a multilayered exodermis, a parenchymatous region, and an endodermis. The exodermis cells are suberized in all species, as detected by Sudan III. In roots of both, stalk and tiller, of the RB867515 variety, the exodermis cells possess a lower degree of suberization, while those of the SP813250 have a higher degree (Figs. 8-12 respectively). In all varieties, the root cortex is formed by layers of parenchymatous cells organized in columns (Figs. 1-6, 13, 14). In order to estimate the number of layers forming the root cortex, we counted the number of columns adjacent to the lysigenous areas (Table 2). The endodermis is one-layered in all roots and formed by isodiametric cells of thickened anticlinal and inner periclinal walls (U-thickening) (Figs. 17-28).

The outer layer of the vascular cylinder, the pericycle, is formed by sclerified cells, in the stalk roots of the SP803250 (Fig. 22). All roots are polyarc and their medullary regions filled with large and isodiametric parenchymatous cells of primary walls and small intercellular spaces. The test with phloroglucin acid detected the presence of sclerenchyma near the metaxylem poles (Figs. 17-28). In the tillers of the RB867515 cultivar, this sclerification is less prominent (Fig. 24). The histochemical tests did not reveal the occurrence of ergastic substances in the epidermis, cortex, or in the medullary region. For all samples, the tiller roots possess greater cortical and vascular diameters than the stalk roots. These differences in 
Table 1 Histochemical tests carried out on roots from stalks and tillers of sugar cane genotypes

\begin{tabular}{lll}
\hline Histochemical analysis & & Concentrations \\
\hline Substance & Histochemical test & \\
\hline Flavonoids & Potassium hydroxide (Costa 1982) & $5 \%$ \\
Lignin & Phloroglucinol hydrochloride (Jansen 1962) & $20 \%(\mathrm{v} / \mathrm{v})$ \\
Lipids/suberin & Sudan III (Johansen 1940) & $3 \%$ \\
Starch & Lugol's solution (Bucherl 1962) & $1 \%$ \\
\hline
\end{tabular}
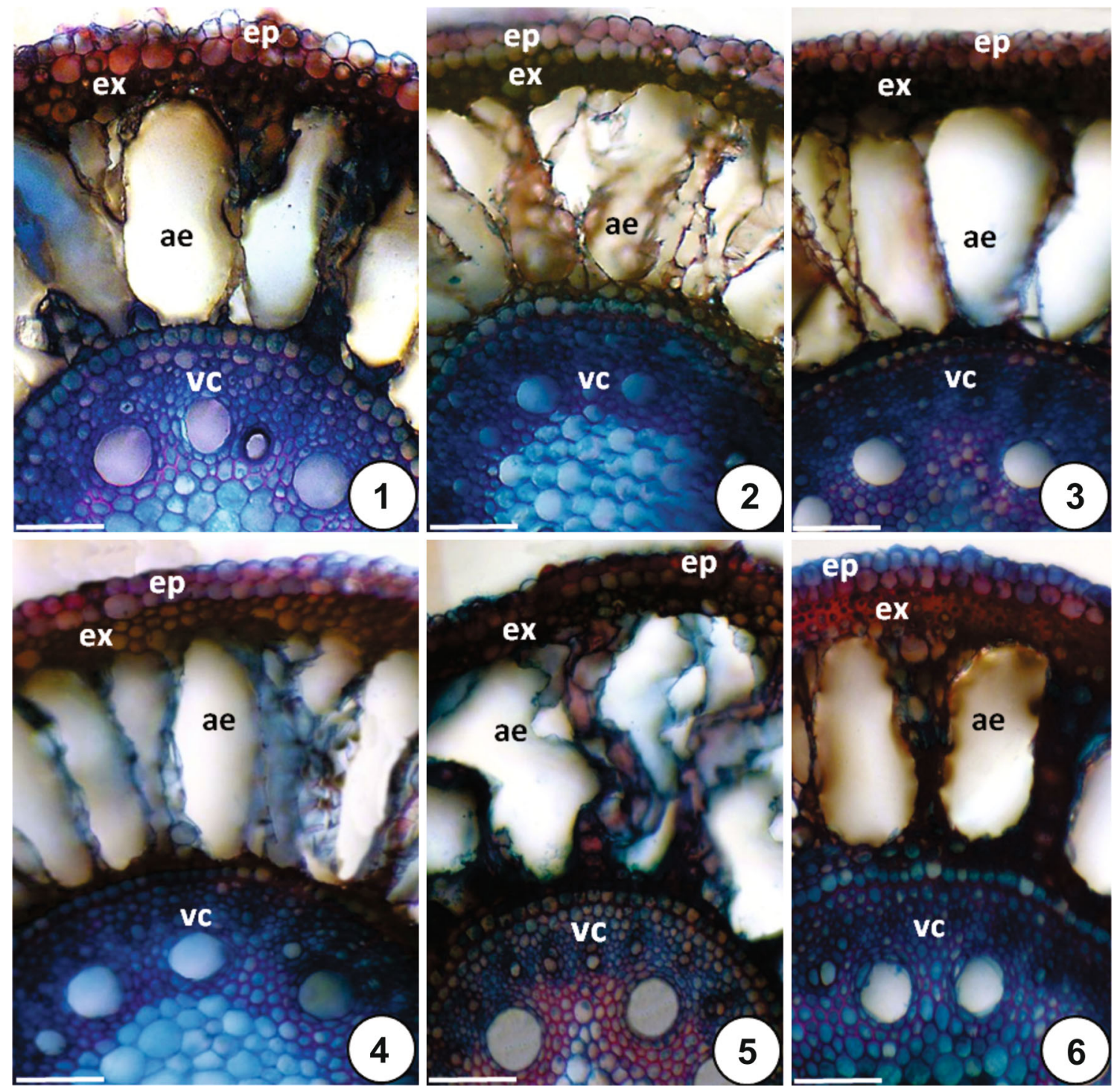

Figs. 1-6 Cross sections showing the general structure of the roots of stalks of different genotypes of Saccharum. 1 RB855453. 2 RB867515 (drought tolerant by fewer cortical layers). 3 SP801816 (drought intolerant by the highest number of cortical layers and poles

of protoxylem). 4 SP801842. 5 SP803280. 6 SP803250. The suberization of exodermises of all cultivars was evidenced by realization of histochemical test with Sudam III. ae aerenchyma, $v c$ vascular cylinder, ep epidermis, ex exodermis. Bar $150 \mu \mathrm{m}$

higher number of cortical parenchyma layers than those surviving under such conditions (TD) (Table 2). We also noted a variation in the exodermis layer number between the stalks and tillers of the genotypes SP801842 and 

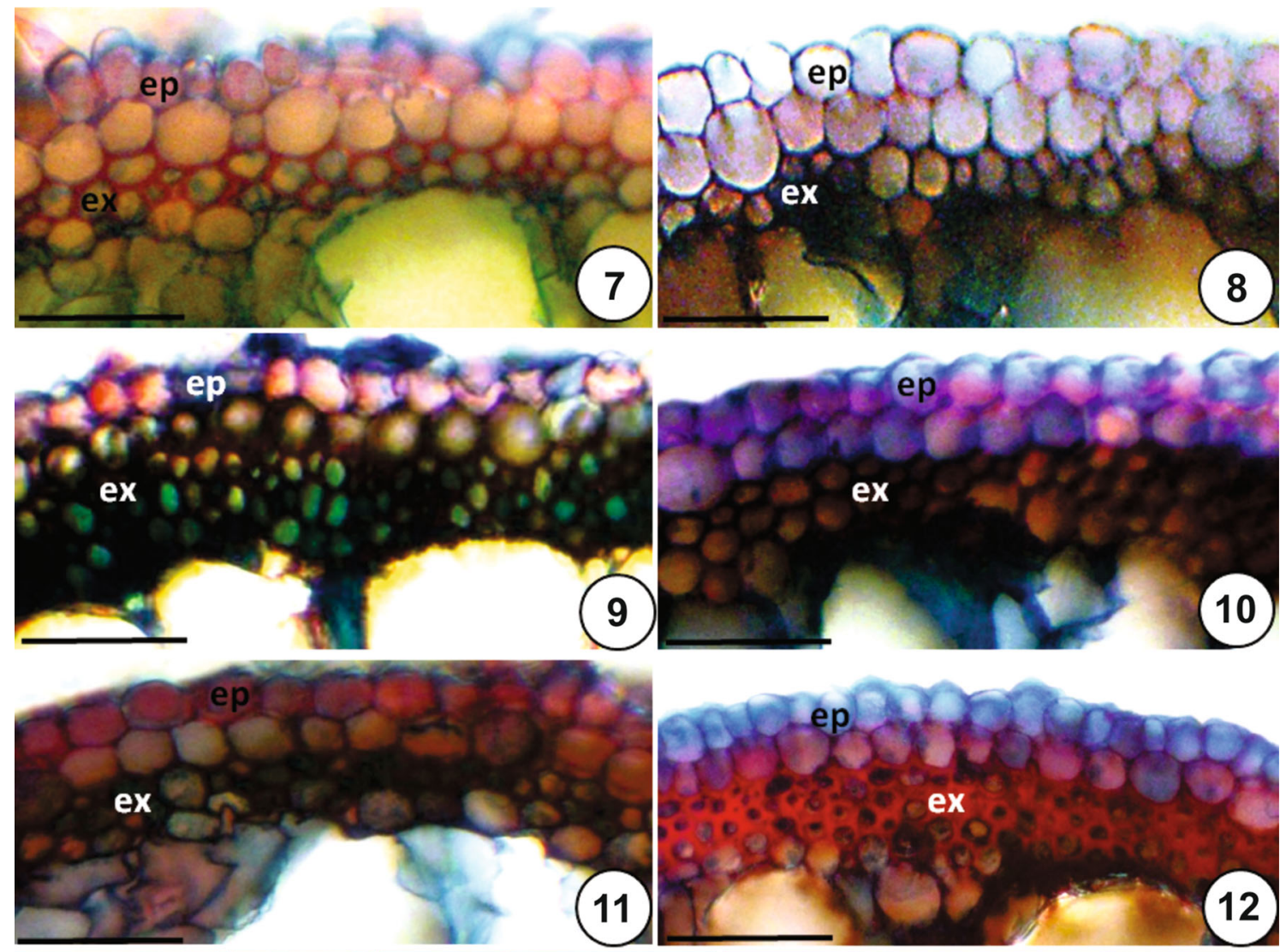
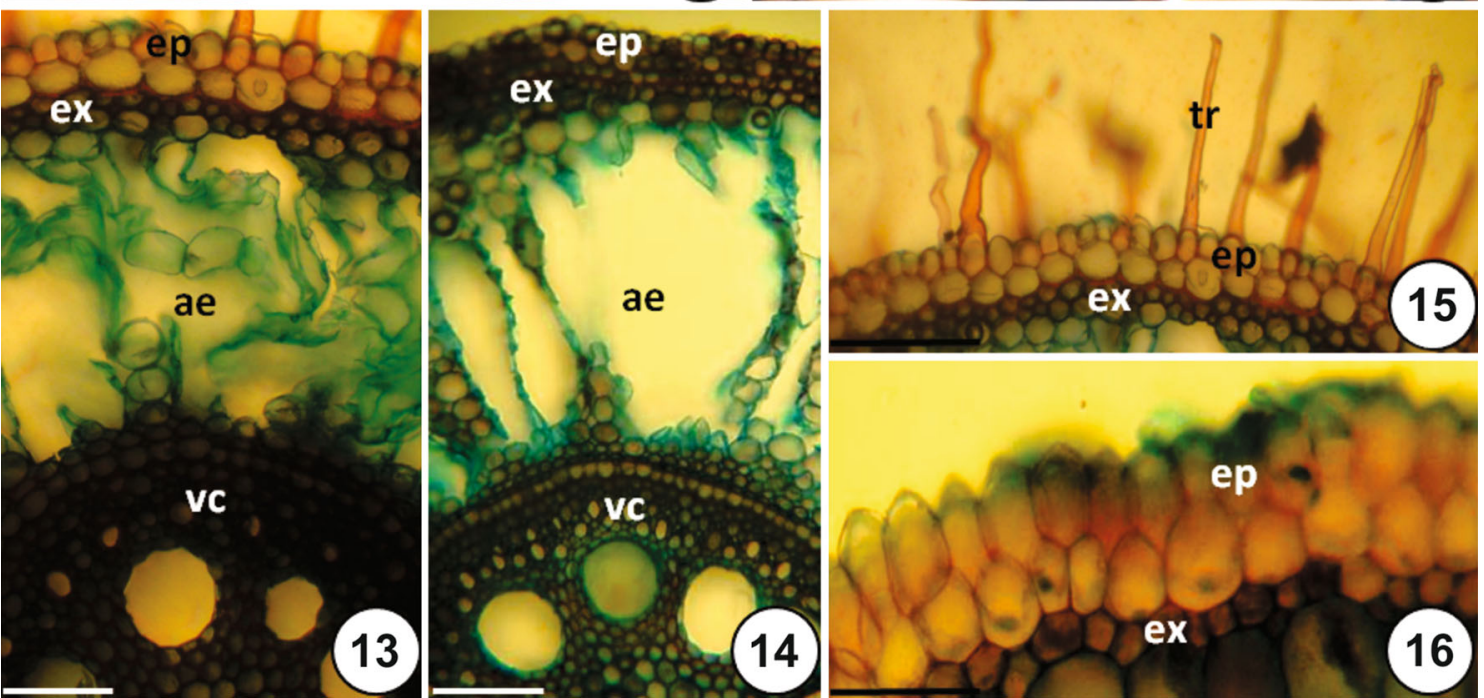

Figs. 7-16 Cross sections showing the epidermis composed of polygonal cells and suberization of exodermises of stalks. The suberization of exodermises of all cultivars was evidenced by realization of histochemical test with Sudam III. 7 RB855453. 8 RB867515 (lower degree of exodermic suberization). 9 SP801816. 10 SP801842. 11 SP803280. 12 SP803250 (higher degree of exodermic

SP803280. Thus, by describing details of root structure in both stems and tillers, it may prove possible to identify adaptations providing resistance to water stress in these organs and to select features useful for identifying each cultivar of the studied genotypes. suberization). Radicular general structures: 13 SP803280 and 14 SP803250. Epidermis and exodermises of tillers: 15 SP803280 (trichome present). $16 \mathrm{RB} 855453$. ae aerenchyma, $v c$ vascular cylinder, ep epidermis, ex exodermis, tr trichomes. Bars $50 \mu \mathrm{m}$ (7-12, 15-16), $150 \mu \mathrm{m}(13-14)$

\section{Discussion}

To secure the production of sugar and alcohol in Brazil, it is necessary to ensure high productivity of the sugar cane crop. Genetic improvement to develop cultivars with 


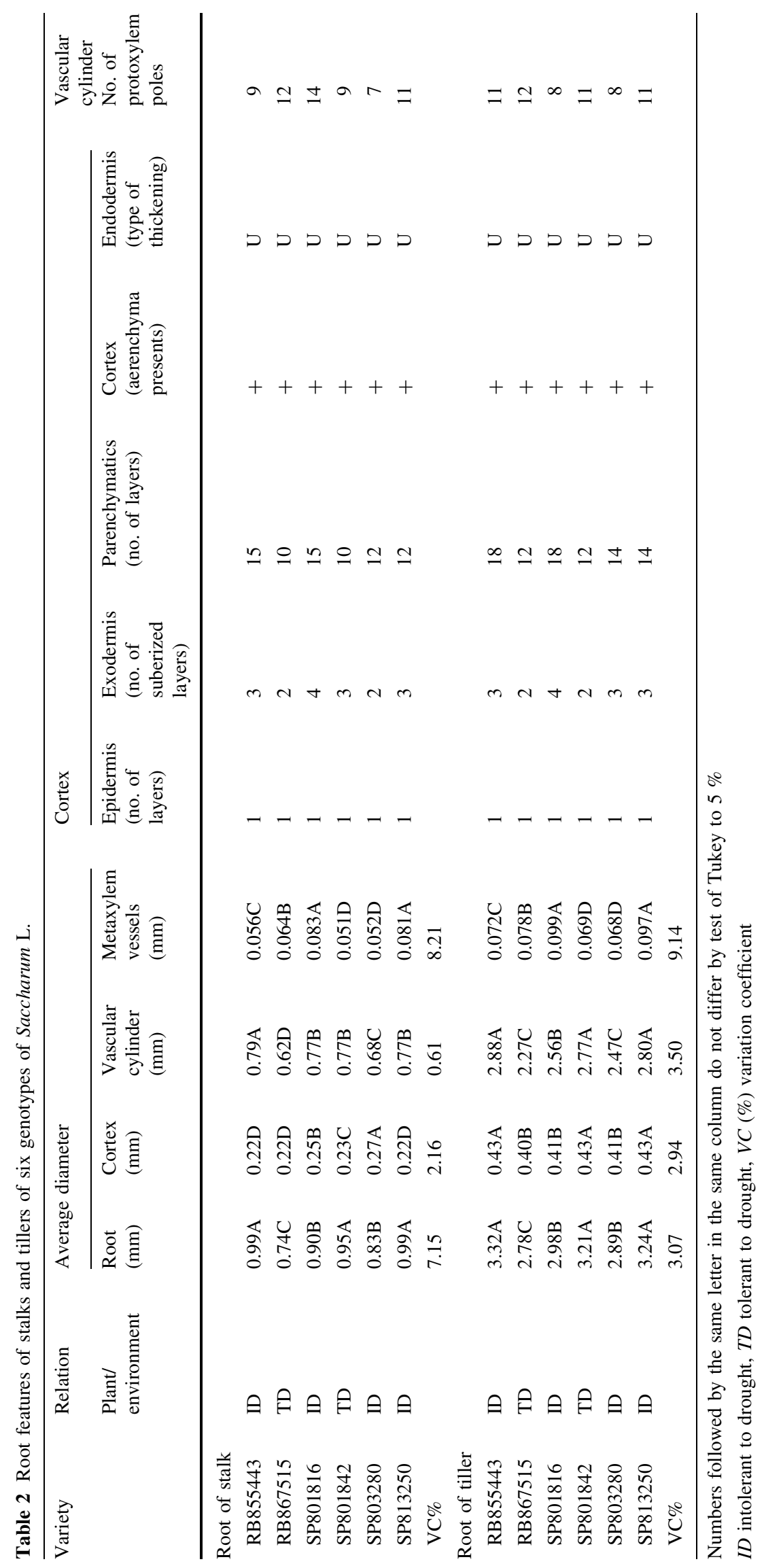


Figs. 17-28 Cross sections showing the vascular cylinder of stalks (17-22) and tillers (23-27) of genotypes of Saccharum. 17 and 23 RB855453. 18 and 24 RB867515 (lower medullar sclerification in the tiller). 19 and 25 SP801816. 20 and 26 SP801842. 21 and 27 SP803280. 22 and 28 SP803250 (sclerification pericyclic present in the stalks). en endodermis, $p e$ perycicle, me medulla. The sclerification of parenchyma cells in vascular cylinder was demonstrated histochemically by Sudam III. Bar $150 \mu \mathrm{m}$
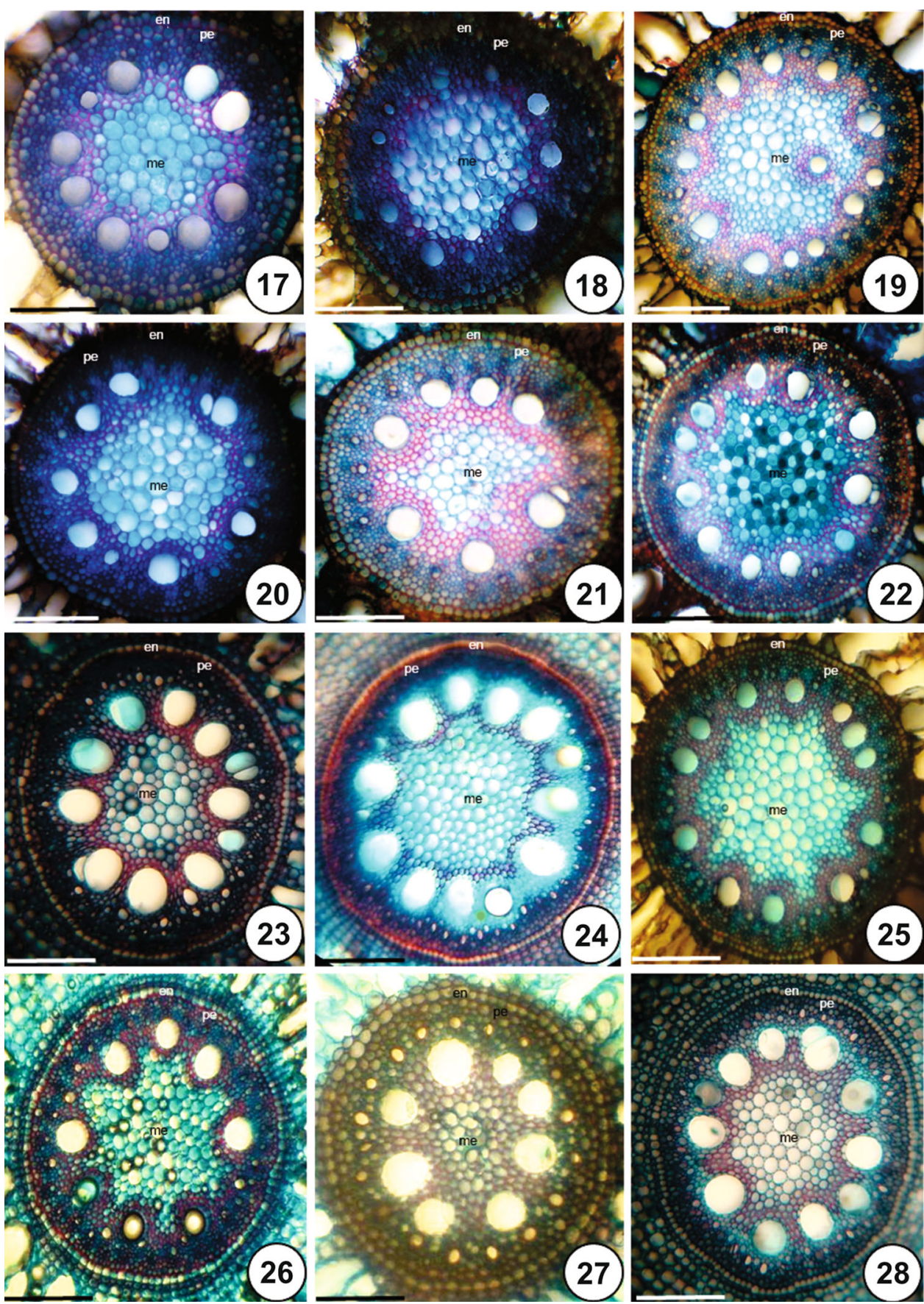

genotypes better adapted to resist stressful conditions related to soil or climate can contribute to increased productivity (Marin 2015). In particular, the relative tolerance or susceptibility of Saccharum cultivars to drought may have a great impact on agricultural productivity (Pimentel 2004; Inman-Bamber and Smith 2005). As an example, one can cite the tolerance of the genotypes SP801842 and RB867515 that maintain their quality and productivity during the dry season because of their delayed maturing (Prado 2005; Ferreira et al. 2007; Cruz et al. 2014).
Understanding the anatomical characters related to the negative effects of water stress in sugar cane plants may lead to improvements in the biomass production (InmanBamber 2004).

In many cultivars, water stress causes severe leaf senescence and restriction of foliar neogenesis (Machado et al. 2009). The extent of such changes is due to the intensity of water stress and depends on the genotype (Smit and Singels 2006). To grow sugar cane, it is necessary to cater for the fact that plants require a plentiful supply of 
water during their development phase, which comprises tillering and fast growth, and occurs between 60 and 150 days after planting (Ramesh 2000). The susceptibility of sugar cane to water stress is greater when plants are in the stem elongation phase (Inman-Bamber and Smith 2005), so drought during this phase causes serious damage to biomass production and sucrose yield (Robertson et al. 1999; Silva and Costa 2004), as reported for the intolerant genotypes RB801816, RB855453, SP803280, and SP813250 (Maule et al. 2001; Prado 2005; Marin 2015).

However, there are genotypic variations in sugar cane regarding their tolerance to water deficit (Saliendra et al. 1996; Inman-Bamber and Smith 2005; Inman-Bamber et al. 2005). This tolerance is multigenically controlled (Rodrigues et al. 2009) and expressed at different organizational levels, ranging from cellular responses to anatomical-morphological variations (Passioura 1982). In this regard, low-cost methods enabling the identification of tolerant and susceptible genotypes to drought, such as root anatomical analysis, as applied in the present investigation could prove of wide agronomic importance.

Some of the anatomical features described here for the sugar cane roots, such as suberized exodermis, cortical lysigenous aerenchyma, and endodermis with U-thickening, have also been reported for other Poaceae, such as Paspalum dilatatum (Vasellati et al. 2001), P. paniculatum, Setaria anceps (Melo et al. 2007), Zea mays "Saracura" BRS-4154 (Pereira et al. 2008), and various cultivars of Saccharum (Venkatraman and Thomas 1922; Artschwager 1925; van Dillewijn 1952; Trouse Jr 1967; Queiroz-Voltan et al. 1998). These characteristics demonstrate synapomorphies established during the diversification of the family that can be used for taxonomic characterization of genera and species (Almeida et al. 2009).

A common feature of the roots of monocots is the sclerification of the pericycle that reduces the morphogenic competence of this layer to form lateral roots (Ferri 1999; Raven et al. 2007). In the cultivars described in the present study, sclerified pericycle occurs only in the tolerant SP803250 roots, enabling the differentiation of this genotype from the other investigated cultivars.

In all cultivars, the root structure of stalks and tillers is similar to that reported for species growing in natural conditions (Artschwager 1925; van Dillewijn 1952) and in compacted soil (Venkatraman and Thomas 1922; Trouse Jr 1967). Queiroz-Voltan et al. (1998) made biometric descriptions of the root cortex and vascular cylinder diameters of the cultivar SP701143 growing in Oxisol. Both in stalk and tiller roots, the cortex and vascular cylinder diameters influence the overall of the root diameter. This is confirmed by the fact that in many monocots, such as terrestrial orchids, the numbers of cortical layers and protoxylem poles are directly correlated with root diameter (Moreira and Isaias 2008). However, each one will influence the overall diameter to variable extents, since they are affected by environment influences that in turn also affect root diameter (Pedroso-de-Moraes et al. 2012). This relationship has been shown for plants of the same species grown under variable conditions of water supply, where the shortest distance between the substrate and the stele (fewer cortical layers) can facilitate the absorption of water (Fahn 1982). Thus, it can be suggested that plants adapted to water scarcity have a naturally reduced cortical diameter, as shown by the cultivar RB867515, commonly described as tolerant to drought (Prado 2005; Cruz et al. 2014) (Table 2).

A study of upland rice grown under excessive irrigation reported an increase in cortical thickness (Duarte et al. 1993). For different sugar cane cultivars growing in different soil conditions (dry, irrigated, and soggy), differences in root anatomy were reported, mainly related to the thickness of cortex and vascular cylinder (Venkatraman and Thomas 1922). The root cortex is thicker in plants growing in irrigated and soggy soils (Venkatraman and Thomas 1922). This agrees with observations made in the present study, where the highest number of parenchymatous layers was observed in the root cortex of drought intolerant and the lowest in drought tolerant cultivars (Table 2). Venkatraman and Thomas (1922) also reported, for different varieties of sugar cane, that the parenchyma cells located between the poles of xylem and phloem possess a more prominent wall thickening in roots grown under drought conditions. This corroborates the greater thickening found in this root region of the stalks and tillers of the cultivar SP803280 (Figs. 21, 27; Table 2).

Especially in monocots, there is a close relationship between root diameter and the number of protoxylem poles, which varies in different roots of the same species, and in the same root, at different levels (Rütter and Stern 1992; Rosso 1966). This does not seem to be the case in the studied species, as the cultivars with the highest number of protoxylem poles, in roots of both stalks and tillers, do not show the largest root diameters (Table 2). This was also reported for other sugar cane cultivars, where the root diameter is related to the diameter of metaxylem elements rather than the number of protoxylem poles (Venkatraman and Thomas 1922; Artschwager 1925; van Dillewijn 1952; Trouse Jr 1967; Queiroz-Voltan et al. 1998). This may relate to possibility that the number of protoxylem poles in Saccharum can be influenced by environmental features, such as physical and chemical soil conditions, water supply, light intensity, temperature, diseases, and pests and competition with weeds (Trouse Jr 1967).

Reductions in diameter of the metaxylem elements, and consequently in the vascular cylinder, is commonly found in plants under stress, particularly water stress, and may 
result in a greater resistance to water flow (Passioura 1982; Melo et al. 2007). The vessel diameter is adaptable, since species originated or adapted to dry environments have narrower vessels than species from moist environments (Carlquist 1988). This is in agreement with the observed here for the tiller and stalk roots of the cultivar RB867515, considered to be drought tolerant (Table 2). In this case, vessel diameter seems to be genetically determined, since it remained unchanged even under controlled conditions of temperature, light, and humidity, as observed in this study.

A thin root cortex, filled of aerenchymatous parenchyma in plants subjected or adapted to water deficiency, as observed for the stalks and tillers of some species (Figs. 5, 7-16), may prevent water loss from the plant to the soil (Huck et al. 1970). If the thickness of the root cortex changes with its hydric potential this may in turn cause contraction of the cortical cells, reducing their volume (Huang and Fry 1998). With the reduction of cortex tissue volume, the air space in the aerenchyma is positioned closer to the exodermis and epidermis, thus avoiding excessive loss of water from the internal compact tissue adjacent to the vascular cylinder (Melo et al. 2007).

Lysigenous aerenchymas are produced by cell apoptosis triggered by the phytohormone ethylene, in plants subjected to stress conditions (Drew 1997), such as mechanical damage, nutritional deficiency, and hypoxia/anoxia (Bouranis et al. 2006). Among these factors, the most effective is hypoxia/anoxia as low levels of oxygen stimulate ethylene synthesis that can cause a delay in root elongation. In several Poaceae (Vasellati et al. 2001; Bouranis et al. 2006; Melo et al. 2007; Pereira et al. 2008), aerenchyma development allows the formation of intercellular spaces connecting the root axis. It facilitates gas diffusion (Gunawardena 2008) allowing a better distribution of $\mathrm{O}_{2}$ in the tissues, thus maintaining aerobic respiration and cellular metabolism (Pereira et al. 2008).

Roots of species susceptible to desiccation tend to develop different anatomical features to prevent excessive water loss (Fahn 1982). This is confirmed in this investigation as the cultivar SP801816, considered intolerant to water scarcity, possesses the highest number of layers in the exodermis, in both stalks and tillers (Table 2). The presence of a thick barrier in cell walls, by the deposition of suberin, prevents the radial loss of oxygen to the rhizosphere while increasing its longitudinal diffusion in the aerenchyma (Colmer 2003). However, this barrier can decrease the effect of ethylene and methane and the entrance of water and nutrients (Soukup et al. 2002). Thus, thin exodermis allows free radial movement of oxygen and creates aerated conditions in the rhizosphere, protecting the roots against phytotoxins (Armostrong et al. 2000; Soukup et al. 2002).

The deposit of suberin in cell walls restricts the apoplastic route for diffusion of water, as it is a hydrophobic compound (Mauseth 1988). Thus, the suberized exodermis, in roots of the cultivar RB867515, may reduce the flow of water and minerals throughout the epidermis-cortex-cylinder. Exodermis cells with low amounts of suberin facilitate water movement and may indicate potential cultivar productivity. Maybe for this reason, the RB867515 genotype maintains its productivity during the dry season (Prado 2005; Ferreira et al. 2007; Cruz et al. 2014). In this genotype, the exodermis cells are poorly suberized, and its tolerance to water scarcity is due mainly to the lower number of cortical layers together to the high number of protoxylem poles.

Roots with a parenchymatous center of large cells and small intercellular spaces, as observed for all stalk and tiller roots, are common within Saccharum (Venkatraman and Thomas 1922; Artschwager 1925; van Dillewijn 1952; Trouse Jr 1967; Queiroz-Voltan et al. 1998).

Some results obtained here, such as the number of layers and cell features of the exodermis and cortex layers and the number of the protoxylem poles, can be useful in the identification of cultivars. These anatomical features of roots could also be taken to determine the tolerance or intolerance of plants to drought, as they can provide information on physiological characters, such as root hydraulic conductance, root-shoot signaling, photosynthesis, transpiration, and chlorophyll levels. The features of roots in the cultivars of Saccharum that seem more related to drought tolerance are cortex diameter and its number of layers. Drought intolerant species exhibit, in general, a greater number of cortical layers and protoxylem poles, which may make them more susceptible to desiccation.

Acknowledgments We thank Prof. Edwin W. Taylor, Emeritus Professor at the University of Birmingham, UK and Nicolas Z. dos Santos, Msc. in Molecular Plant Sciences and Research Associate of Monsanto, for proofreading this work.

\section{References}

Almeida CMA, Lima SEN, Lima SGA, Brito JZ, Donato VMTS, Silva MV (2009) Molecular characterization of the sugarcane cultivars obtained by ISSR markers. Cienc Agrotecnol 33:1771-1776

Armostrong W, Cousins D, Armostrong J, Turner JW, Beckett PM (2000) Oxygen distribution in wetland plant roots and permeability barriers to gas-exchange with the rhizosphere: a microelectrode and modeling study with Phragmites australis. Ann Bot 86:687-703

Artschwager E (1925) Anatomy of the vegetative organs of sugar cane. J Agric Res 30:197-221

Bouranis DL, Chorianopoulou SN, Kollias C, Maniou P, Protonotarios VE, Siyiannis VF, Hawkesford MJ (2006) Dynamics of aerenchyma distribution in the cortex of sulfate-deprived adventitious roots of maize. Ann Bot 97:695-704

Bucherl W (1962) Técnica microscópica. Polígono, São Paulo

Bukatsh F (1972) Benerkemgem zeir doppelfarbeing astrablausafranina. Mikrokosmos 61:255-256 
Caputo MM, Beauclair EGF, Silva MA, Piedade SMS (2008) Resposta de genótipos de cana-de-açúcar à aplicação de indutores de maturação. Bragantia 67:15-23

Carlquist S (1988) Comparative wood anatomy: systematic, ecological and evolutionary aspects of dicotyledons wood. Springer, Berlin

Chaves A, Pedrosa EMR, Pimentel RMM, Coelho RSB, Guimarães LPM, Maranhão SRVL (2009) Resistance induction for Meloidogyne incognita in sugarcane through mineral organic fertilizers. Braz Arch Biol Technol 52:1393-1400

Colmer TD (2003) Aerenchyma and an inducible barrier to radial oxygen loss facilitate root aeration in upland, paddy and deepwater rice (Oryza sativa L.). Ann Bot 91:301-309

Costa AF (1982) Farmacognosia. Fundação Calouste Gulbenkian, Lisboa

Cruz LR, Gerassev LC, Carmo TD, Santos LDT, Barbosa EA, Costa GA, Santos Júnior A (2014) Características agronômicas e composição bromatológica de variedades de cana-de-açúcar. Biosci J 30:1779-1786

Drew MC (1997) Oxygen deficiency and root metabolism: injury and acclimation under hypoxia and anoxia. Ann Rev Plant Physiol Plant Mol Biol 48:223-250

Duarte AP, Voltan RBQ, Furlani PR (1993) Amarelecimento do arroz-de-sequeiro sob condições de encharcamento em solo de baixa fertilidade. Bragantia 52:139-152

Enstone DE, Peterson CA (2005) Suberin lamella development in maize seedling roots grown in aerated and stagnant conditions. Plant Cell Environ 28:444-455

Fahn A (1982) Plant anatomy, 3rd edn. Pergamon Press, Oxford

Ferreira EA, Ventrella MC, Santos JB, Barbosa MHP, Silva AA, Procópio SO, Silva EAM (2007) Leaf blade quantitative anatomy of sugarcane cultivars and clones. Planta Daninha 25:25-34

Ferri MG (1999) Botânica: morfologia interna das plantas. Nobel, São Paulo

Gunawardena AH (2008) Programmed cell death and tissue remodelling in plants. J Exp Bot 59:445-451

Huang B, Fry JD (1998) Root anatomical physiological and morphological to drought stress for tall fescue cultivars. Crop Sci 30:1017-1022

Huck MG, Keples BL, Taylor HM (1970) Diurnal variations in root diameter. Plant Physiol 45:529-530

Inman-Bamber NG (2004) Sugarcane water stress criteria for irrigation and drying off. Field Crops Res 89:107-122

Inman-Bamber NG, Smith DM (2005) Water relations in sugarcane and response to water deficits. Field Crops Res 92:85-202

Inman-Bamber NG, Bonnett GD, Smith DM, Thorburn PJ (2005) Sugarcane physiology: integrating from cell to crop to advance sugarcane production. Field Crops Res 92:115-117

Jansen WA (1962) Botanical histochemistry. H.H. Freeman \& Co, San Francisco

Johansen DA (1940) Plant microtechnique. Mc Graw Hill, New York

Machado RS, Ribeiro RV, Marchiori PER, Machado DFSP, Machado EC, Landell MGA (2009) Respostas biométricas e fi siológicas ao defi cit hídrico em cana-de-açúcar em diferentes fases fenológicas. Pesq agropec Bras 44:1575-1582

Marin FR (2015) Embrapa-Árvores do conhecimento-cana-deaçúcar: variedades. http://www.agencia.cnptia.embrapa.br/ges tor/cana-de-acucar/arvore/CONTAG01_42_1110200717570.html. Accessed 12 May 2015

Maule RF, Mazza JA, Martha Júnior GB (2001) Produtividade agrícola de cultivares de cana-de-açúcar em diferentes solos e época de colheita. Sci Agric 58:295-301

Mauseth JD (1988) Plant anatomy. The Benjamin/Cummings Publishing Company Inc, California
Melo HC, Castro EM, Soares AM, Melo LA, Alves JD (2007) Alterações anatômicas e fisiológicas em Setaria anceps Stapf ex Massey e Paspalum paniculatum L. sob condições de déficit hídrico. Hoehnea 32:145-153

Moreira ASFP, Isaias RMS (2008) Comparative anatomy of the absorption roots of terrestrial and epiphytic orchids. Braz Arch Biol Technol 51:83-93

Passioura JB (1982) Water in soil-plant-atmosphere continuum. In: Lange OL, Nobel PS, Osmond DB, Ziegler H (eds). Physiological plant ecology II. Encycl Plant Physiol 12:5-33

Pedroso-de-Moraes C, Souza-Leal T, Brescansin RL, Pettini-Benelli A, Sajo MG (2012) Radicular anatomy of twelve representatives of the Catasetinae subtribe (Orchidaceae: Cymbidieae). An Acad Bras Cienc 84:209-221

Pereira FJ, Castro EM, Souza TC, Magalhães PC (2008) Evolução da anatomia radicular do milho 'Saracura' em ciclos de seleção sucessivos. Pesq Agropec Bras 43:1649-1656

Pimentel C (2004) A relação da planta com a água. Edur, Seropédica

Prado H (2005) Ambientes de produção de cana-de-açúcar na região central do Brasil. Inf Agron 110:12-17

Procana (2010) Os impressionantes números do setor sucroenergético (Safra 2009/10). http://www.jornalcana.com.br/Conteudo/Con heca\%20o\%20Setor.asp. Accessed 4 Nov 2010

Queiroz-Voltan RB, Prado H, Moretti FC (1998) Aspectos estruturais de raízes de cana-de-açúcar sob o efeito da compactação do solo. Bragantia 57:12-19

Ramesh P (2000) Effect of different levels of drought during the formative phase on growth parameters and its relationship with dry matter accumulation in sugarcane. J Agron Crop Sci 185:83-89

Raven PH, Evert RF, Eichhorn SE (2007) Biologia vegetal, 7th edn. Guanabara Koogan, Rio de Janeiro

Robertson MJ, Muchow RC, Donaldson RA, Inman-Bamber NG, Wood AW (1999) Estimating the risk associated with drying-off strategies for irrigated sugarcane before harvest. Aust J Agric Res 50:65-77

Rodrigues FA, Laia ML, Zingaretti SM (2009) Analysis of gene expression profiles under water stress in tolerant and sensitive sugarcane plants. Plant Sci 176:286-302

Rosse LN, Vencovsky R, Ferreira DF (2002) Comparação de métodos de regressão para avaliar a estabilidade fenotípica em cana-deaçúcar. Pesq Agropec Bras 37:25-32

Rosso SW (1966) The vegetative anatomy of the Cypripedioideae (Orchidaceae). Bot J Linn Soc 59:309-341

Rutter BE, Stern WL (1992) An assessment of quantitative features of velamen stratification and protoxylem strands in roots of Orchidaceae. Lindleyana 9:219-225

Saliendra NZ, Meinzer FC, Perry M, Thom M (1996) Associations between partitioning of carboxylase activity and bundle sheath leakiness to $\mathrm{CO}_{2}$, carbon isotope discrimination, photosynthesis, and growth in sugarcane. J Exp Bot 47:907-914

Silva ALC, Costa WAJM (2004) Varietal variation in growth, physiology and yield of sugarcane under two contrasting water regimes. Trop Agric Res 16:1-12

Smit MA, Singels A (2006) The response of sugarcane canopy development to water stress. Field Crops Res 98:91-97

Soukup A, Votrubova O, Ciskova II (2002) Development of anatomical structure of roots of Phragmites australis. New Phytol 153:277-287

Trouse AC Jr (1967) Effects of soil compression on the development of sugar cane roots. In: Congress of the international society of sugar cane technologists, 12, San Juan, 1965. Proceedings of Amsterdam, international society of sugarcane technologists, pp 137-152

van Dillewijn C (1952) Botany of sugarcane. The Chronica Botanica, Waltham 
Vasconcelos ACM (1998) Comportamento de clones IAC e variedades de cana-de-açúcar (Saccharum spp.) nas condições edafoclimáticas da região do Vale do Paranapanema. Jaboticabal, 1998, p 108. Dissertação (Mestrado em Produção Vegetal)_Faculdade de Ciências Agrárias e Veterinárias, Universidade Estadual Paulista
Vasellati V, Oesterheld M, Medan D, Loreti J (2001) Effects of flooding and drought on the anatomy of Paspalum dilatatum. Ann Bot 88:355-360

Venkatraman TS, Thomas R (1922) Sugarcane root systems: studies in development and anatomy. Agric J India 17:381-388 